\title{
WINNING HEARTS AND MINDS IN THE NAMIBIAN BORDER WAR
}

\author{
Lieneke Eloff de Visser ${ }^{1}$
}

\begin{abstract}
During the Namibian border war, South African counterinsurgency doctrine acknowledged the importance of securing the allegiance and cooperation of the population. This article demonstrates that, in the operational zone, the responsibility of winning the hearts and minds of the Namibian people largely fell to the SADF (South African Defence Force). Although the SADF dedicated considerable resources to this task, these efforts were often at cross-purposes with those of institutions in the political, police and administrative domains. In addition, there was a lack of unity and purpose within the SADF. This article argues that lack of unity between and within the different domains undermined the effort at winning the hearts and minds of the Namibian population, and must at least partly have contributed to SWAPO's victory in the 1989 elections.
\end{abstract}

\section{Introduction}

In devising appropriate responses to the challenges of the Namibian border war (1974-1989), the South African military drew on the work of C.A. 'Pop' Fraser and John McCuen. Fraser, a WWII veteran, became Chief of Joint Operations of the South African Defence Force in 1966. In an unpublished study entitled Lessons learnt from past revolutionary wars, released in the early sixties, Fraser distilled the basic principles of counterinsurgency warfare from the work of authors such as Galula and Trinquier. McCuen served in staff and command positions in the United States Army in Vietnam, Thailand, Germany and Indonesia. While serving on the US Army General Staff in 1966 his book, The Art of Counter-Revolutionary WarThe Strategy of Counter-Insurgency, was published.

Scientia Militaria, South African Journal of Military Studies, Vol 39, Nr 1, 2011, pp. 85-100. doi: $10.5787 / 39-1-103$
The writings by Fraser and McCuen were disseminated to military command and staff at the SADF training institutes and were a primary source of South African doctrine. ${ }^{2}$ 
What then did the South African military learn from these writers? A shared point of departure is their agreement on the importance of winning the sympathy and support of the people upon whom insurgents depend for resources, intelligence, recruits and places of hiding, also known as 'winning the hearts and minds' (WHAM). ${ }^{3}$ Indeed, SADF top commanders like Magnus Malan, Constand Viljoen, Jannie Geldenhuys and Georg Meiring attached great importance to gaining the cooperation of the population. ${ }^{4}$ On Gen. Viljoen's orders, a series of publications on the subject were distributed among officers and commanders. ${ }^{5}$ In addition, lectures were arranged and from 1978 onward operational staff was required to attend training courses. ${ }^{6}$ The SADF also put considerable effort into the socio-economic development of northern Namibia and propaganda campaigns among its population. The first part of this article briefly outlines these efforts.

Fraser and McCuen state that counterinsurgency involves an interlocking system of political, economic, administrative, police and military efforts. Consequently, the overall direction of a counterinsurgency war belongs with the civilian power, and the armed forces are but one of many instruments at its disposal. ${ }^{7}$ In this respect, McCuen refers to Mao's dictum that 'the Party commands the gun' and furthermore states that unity of purpose and effort is paramount, so that an action in one of the domains should be carefully coordinated with and weighed up against its effects in other domains. ${ }^{8}$ The second part of this article demonstrates that in the Namibian border war, this unity was often lacking, and thus had a detrimental effect on SADF efforts at winning the hearts and minds of the Namibian population in the operational zone.

\section{WHAM - Winning Hearts and Minds}

The focus of SADF efforts to gain the cooperation of the population was on socio-economic help, instilling respectful attitudes towards the population, and propaganda campaigns aimed at persuading the population of the SADF's good intentions, while undermining support for SWAPO.

Socio-economic development, also called civic action, was far more extensive than the development of infrastructure around and between the military bases, which was essentially a by-product of the SADF presence. According to an SADF publication, in the operational area the number of schools increased from 212 in 1962 to 757 in 1982, while the number of pupils increased from 32000 to 172000 . National servicemen were deployed in the education, health, agriculture, forestry and nature preservation fields. In addition to medical services, all dentists, veterinarians and psychologists in the operational area were linked to the SADF civic action. ${ }^{9}$ The 
population was further encouraged to cooperate by monetary rewards. A poster of the time lists the rewards as R5 000 for an RPG launcher, R2 000 for information leading to the capture of a SWAPO insurgent, R1 000 for a landmine, R500 for an AK47, R100 for a mortar bomb, R100 for a hand grenade and R100 for a jumping-jack antipersonnel mine. ${ }^{10}$

Since regular troops could have come into contact with the local population while out on patrol, great effort was put into promoting a respectful attitude towards the population. Ethnologists were employed to educate troops on local family structures, living arrangements, agricultural activities and cultural traditions. Troops were advised on proper etiquette and were offered a phrase list, featuring questions such as, "Where is water?" and "Did strangers visit you?",1

Propaganda efforts among the population, loosely known as 'psychological action' or 'psy-ops', were complicated by the fact that a large part of the population was illiterate and had no access to modern media such as television. Alternatives were the distribution of pamphlets with cartoon-like messages, sky-shout and ground-shout operations. ${ }^{12}$ These were meant to discredit SWAPO, and convince the population of the SADF's good intentions, as well as its military strength. This served a double objective of demoralising insurgents and preventing the population from joining them. $^{13}$

The SADF efforts at WHAM had uneven results. The purpose of WHAM, as stated in Department of Defence publications, points to two main objectives. The first was to obtain intelligence and deny the insurgents food, shelter and intelligence. ${ }^{14}$ This indicates immediate military objectives. In Ovamboland, the quantity and quality of information received from the population got better towards the end of the war. ${ }^{15}$ Indeed, the number of times that information supplied by civilians led to the capture or elimination of SWAPO insurgents, or to the capture of arms caches, rose from sixtyfour in 1983 , to more than two thousand in $1987 .{ }^{16}$

The second objective of WHAM was to cultivate a positive attitude towards the authorities. This was meant to make the population less susceptible to enemy propaganda and more receptive to psychological action by the SA authorities. ${ }^{17}$ The underlying assumption thus was that civic and psychological action could effect a change in attitude and that it would indicate attempts to influence the ideological mindset of the population. Judging these efforts by the electoral results of 1989, they were largely unsuccessful in Ovamboland, a region that was never fully under South African control, since SWAPO was able to capture ninety-two per cent of the votes. By contrast, in regions that were securely under South African control, the results were better. In the Kavango and Caprivi regions, SWAPO captured fifty-two per cent and 
forty per cent of the vote respectively. ${ }^{18}$ This article next explores the factors that may have been conducive or counterproductive to the extensive SADF efforts at winning hearts and minds of the Namibian population.

\section{Lack of unity}

South African doctrine acknowledged that the counterinsurgency in Namibia should be guided by unity of purpose and effort in and between all its domains. In practice, however, the various institutions involved were often at cross-purposes. Problems that confronted the South African military pertained to a lack of unity between the SADF on one side, and the political authorities, the administration and the police force on the other, as well as a lack of unity within the SADF.

\section{The SADF and the politicians}

Like any government embroiled in foreign military ventures, the South African authorities had to be extremely aware of domestic public opinion, and support for the Namibian war could not be taken for granted. ${ }^{19}$ It was also recognised that success, or lack thereof, in Namibia would have had direct repercussions on the credibility of the South African authorities. In the first place, a SWAPO victory would have inspired domestic insurgent organisations, like the ANC, and might have influenced their future strategies. In the second place, it would have had a negative effect on the morale of the white South African population and it was thus imperative that the SADF retain their trust. ${ }^{20}$ To this end, monthly themes were laid down that were to be disseminated through speeches and interviews by senior SADF officials and their wives. ${ }^{21}$ These were reinforced through publications like Paratus. ${ }^{22}$ The South African public had to be convinced of the need for military intervention in Namibia, and Soviet expansionist aspirations were consistently presented as the threat. By this logic, the take-over of Namibia by a communist inspired regime would mean 'Russians on the Orange river', and a consistent message was that domestic security necessitated a military intervention. ${ }^{23}$ Similarly, SWAPO was consistently portrayed as "Marxist, anti-Christian, corrupt, unrepresentative and a minority of activists". ${ }^{24}$ Western powers and organisations like the UN and the World Council of Churches, who objected to South Africa's racial policies and continued occupation of Namibia, were portrayed as playing into the hands of the communists. ${ }^{25}$

The indigenous Namibian population had to be convinced of the need for South Africa's intervention as well. However, in the operational zone, the communist danger was not a cause that resonated with the people and an alternative had to be sought. ${ }^{26}$ Fraser writes at length on the importance of establishing a cause that is 
more attractive than the insurgent cause. He states that a dilemma arises when the main cause of the insurgents is the overthrow of the current authorities, since a government cannot offer solutions that endanger its own position. Government must therefore offer internal autonomy or a variation of it, and insist on evolution in the calm of a peaceful situation. ${ }^{27}$ In agreement with these principles, the South African cause focused on offering autonomous rule to Namibia's ethnic groups, and the authorities had started the implementation of self-governing areas within Namibia. ${ }^{28}$ Accordingly, Gen. Constand Viljoen stated that the South African cause was "selfdetermination within South Africa's economically beneficial milieu" and "preservation of identity of all peoples of Namibia in one nation, without domination by the Ovambo majority". ${ }^{29}$ Gen. Georg Meiring summarised South Africa's cause as "We [the SADF] will handle security until you [the population] can make your own decisions." 30 However, compared to SWAPO's message of freedom and independence, the South African cause was not attractive to the indigenous population. Indeed, the South African plan of ethnic autonomous territories was rejected by the population and the international community. Although, as early as 1975, the South African authorities had declared that Namibians would determine their own political and constitutional future, which in principle opened the door to independence, even though it was perceived to be independence on South African terms. ${ }^{31}$

Fraser wrote that an attractive cause must be reinforced with reforms that address legitimate grievances, which may rest on a history of colonial exploitation. ${ }^{32}$ However, the perceived threat of a communist-inspired regime in Namibia shaped the terms in which the conflict was articulated and could be discussed, that is as a revolutionary war instead of a national liberation or anti-colonial struggle. Political correctness dominated, and pointing out legitimate grievances of the population was akin to pointing a finger at the government or the departments that were not doing their job properly, and was not accepted. ${ }^{33}$ Nevertheless, South Africa did implicitly acknowledge the role of grievances by addressing some of them, for instance by abolishing the contract labour system and apartheid laws, as well as instituting and supporting multi-ethnic political alliances. ${ }^{34}$ The effect was limited, since the fundamental problem of being regarded as an illegitimate occupying foreign force was not overcome. ${ }^{35}$ During cabinet briefings, Gen. Constand Viljoen warned that a political solution had to be found, since the military would not be able to hold out forever. ${ }^{36}$ However, such a solution was not forthcoming and, according to Gen. Viljoen, the foremost problem confronting the WHAM effort of the SADF was thus the political impotence of the National Party of South Africa. ${ }^{37}$ 


\section{The SADF and the administration}

McCuen insisted that before WHAM was implemented, the military had to destroy or neutralise the insurgent organisation and its influence on the population, and they also had to provide the population with effective and stable security in order to escape reprisals by the insurgents. Beyond that, Fraser recognised that WHAM was the responsibility of the administrative authorities, who had to establish contact with the population, impose and enforce control measures and win popular support through constructive work. Recognising that in operational areas civilian control is not always possible, McCuen wrote that, in such a situation, the military might have had to coordinate political, administrative, economic or military endeavours. $^{38}$

Normalisation, that is reinstituting services that may have been disrupted by the conflict, was the responsibility of the Namibian civil authorities, or the Administration, which were ultimately under South African government control. To talk about disruption of services in the operational zone of northern Namibia may not be quite accurate, since in fact community services "left much to be desired". 39 From the 1970s onwards, when it had been accepted that Namibia would eventually become independent, South Africa started the implementation of self-governing ethnic areas, and in 1985 of a transitional government. ${ }^{40}$ Accordingly, the South African authorities launched efforts to prepare and train regional authorities and their administrative personnel for their bureaucratic responsibilities. In Ovamboland for instance, an Ovambo minister would be assisted by an appointed white Namibian or South African civil servant. However, this administrative support was inadequate and did not succeed in sufficiently developing the capabilities of local Namibian officials. There was little dedication to training people, and when perceiving a lack of ability, management capabilities or work ethic, the white civil servant opted to do the job himself. Being unfamiliar with counterinsurgency doctrine, white civil servants also lacked an understanding of the importance of providing good governance to a population in conflict situations. Finally, the white personnel who were sent to rural regions were not always "good quality". 41

As a consequence of these factors, whether lack of dedication, understanding or ability, the SADF became extensively involved in providing public services to the population in the operational zone. It was diplomatically stated that the local authorities who were responsible for community services could not meet the demand and therefore had approached the SADF for help. ${ }^{42}$ Additional factors were that, since Ovamboland remained a contested region throughout the war, conditions were not always safe for administrative personnel to work in. In addition, civil servants were not 
trained to extract information from the population, thus necessitating military involvement in any case. ${ }^{43}$

Although the fledgling administration was often happy with the SADF's assistance, these efforts were not unanimously well received, and at times this became a source of tension, since the SADF demonstrated the administration's incompetence and administrative personnel felt that the SADF trespassed on their terrain. ${ }^{44}$ Being aware of this problem, the SADF directed publications such as Paratus magazine to attribute successful development projects to the civil administration and to downplay SADF involvement, lest antagonism was created. ${ }^{45}$

The SADF was thus in a difficult position. Although doctrine prescribed that after stabilisation the administration should take responsibility for the normalisation process, in practice the administration was not up to the task, which created a vacuum that SWAPO could step into. The SADF therefore had little choice but to become involved. There were unintended side-effects. Military involvement created a perception among the population that the civil authorities had no real aim of helping them. Even worse, the SADF became so effective at delivering services that they undermined the stature of the local administration, that is the native chief minister and his department. In the long term, this posed a serious problem. Since the population knew that it was the SADF, and not the administration, that delivered services, and since the SADF would be leaving upon independence, who were they to vote for in the eventual elections? ${ }^{46}$

\section{The SADF and the police}

The lack of unity that dogged the South African war effort in Namibia was nowhere more apparent than in the divisions between the SADF and the South African Police (SAP). According to Fraser and McCuen, responsibilities of the police force involved identifying, arresting and interrogating insurgent agents and rehabilitating those who could be won over for the government side. To detect and hunt down insurgents, McCuen advised the use of constant government patrols and highly mobile, specially trained strike forces. The authors emphasise the rule of minimum force and warn that repressive police (and military) action had to be avoided since they would have alienated the population. ${ }^{47}$

McCuen's tactics proved well suited to Namibian circumstances. While the army relied mainly on systematic patrolling of the countryside, ${ }^{48}$ the SA Police unit Koevoet (crowbar) developed into a highly effective search-and-destroy unit. Koevoet's mode of operation was well known to the local population. It included the destruction of crops, homes and sometimes a complete kraal, physical abuse and 
torture during interrogation. Particularly offensive was Koevoet's customary way of lashing killed insurgents to the mudguards of their CASSPIRs. Conceivably, this may have undermined the SADF's efforts at educating their troops on the importance of WHAM. While some soldiers were dismayed by Koevoet's coercive methods, more often young troops were in awe of their Rambo-like style. ${ }^{49}$ At the very minimum, troops were presented with the paradox that military doctrine expected them to treat the population with respect and sympathy, so that the people would withhold support from SWAPO and freely give up information, while on the ground they found Koevoet extracting information by force. ${ }^{50}$

It was clear to the military command that Koevoet was committing atrocities, and that the army was tainted with the same brush. Even when reports about police misconduct were considered as exaggerations, it was the perception among the local population that mattered. The question is therefore why the problem was not addressed. In fact, in the Ovamboland sector, where Koevoet mainly operated, attempts by SADF commanders to have Koevoet removed were blocked by politicians. This decision to tolerate Koevoet was a result of give and take at the top level, where the South African Minister of Police and the Minister of Defence vied for influence and power; thus, the status quo was maintained. ${ }^{51}$

The disjuncture between the SADF and SAP stemmed in particular from their differing approaches to the population. While the SADF focus was on establishing good relationships, Koevoet's coercive tactics seriously compromised the SADF's WHAM efforts.

\section{Within the SADF}

In response to the Namibian war, the SADF had to convert from a military force designed for conventional warfare, to one that could fight an insurgency. Part of this was that the SADF had to adopt the principle that support of the population was now the objective of a war that, according to doctrine, could not be won militarily. This represented a total change in culture, and one that was not easy to achieve. Lack of unity concerning WHAM can be partly ascribed to the difficulties this process of adaptation presented.

A point of difference within the military was the question whether the SADF should be involved in WHAM activities at all. Although this was a matter of necessity more than choice, as seen above, it was argued that it was unreasonable to hold basically untrained troops responsible for the implementation of WHAM, a task that properly belonged to non-military departments. ${ }^{52}$ 
Another point of difference was on the priority of winning hearts and minds. Hard to shake was the preoccupation with kills, or 'koppe'. Body counts were routinely published as a measure of success of an operation, and commanders demonstrated their competence foremost by their effectiveness against the enemy insurgent, and only in the second place by establishing good relationships between the troops and the population. This focus was reinforced by a military culture in which the bulk of medals and badges were awarded to soldiers who got the kills. According to Lt Gen. Ian Gleeson “there was a school: if you've got them by the balls and so forth ... They were not worried about winning hearts and minds. They said: we are here to shoot, forget the rest." This attitude pertained especially to commanders who were temporarily brought in for big operations, but also to some commanders who were stationed in the operational zone itself. ${ }^{53}$

Diverging opinions on the importance of good relations with the population translated into diverging opinions on policies and practices, These discordant views trickled down from top command level to the lower ranks. An example is the policy regarding treatment of prisoners. While one officer might make it clear that prisoners, including SWAPO prisoners, were to be treated well, another would remind the troops, "SWAPOs are not prisoners of war." 54 The influence on the lower ranks was thus harmful to the WHAM effort, since it was the corporals and lieutenants who led the patrols and represented the most frequent point of contact with the local population. At the troop level, furthermore, basic military training did not adequately prepare the troops for their role as ambassadors of South Africa's good intentions. Initially, the focus was exclusively on tactical training, and only upon arrival in the operational zone was there some training on the importance of good relations with the population. In later years, these principles were incorporated into the basic training programme. Still, troops did not always take these principles very seriously and, although strictly forbidden, offences were committed against the population. ${ }^{55}$ Punishment for transgressions was usually mild in order not to damage the morale of the troops. ${ }^{56}$ This created resentment among the population who saw perpetrators of serious crimes getting off with light or suspended sentences.

At times, the imperative of winning popular support clashed with the goal of establishing security. McCuen had little guidance to offer in this regard. He advised that the military should not accept a "few neutral civilian casualties to get a few rebels," and adds that people immediately recognise and resent flagrant disregard of life and property. ${ }^{57}$ However, he furthermore states that indirect coercion, in the form of curfews, control of movement, forbidden zones and resettlement of people and villages, must sometimes be used in order to break the insurgent grip on the population. ${ }^{58}$ The so-called Jati strip along the Angolan border is an example of such 
an attempt, as kraals were forced to move away from a $1 \mathrm{~km}$-wide cordon sanitaire. Although the Jati was presented as a valuable contribution to the safety of the population, the threat of being shot on sight created resentment among the local population who often had family living on the opposite side of the border. ${ }^{59}$ Measures like dusk-to-dawn curfews and forbidden zones in the operational area thus created grievances among the population. ${ }^{60}$

In Namibia, and especially in Ovamboland, the dilemma of having to win the support of the population, while at the same time establishing military control, impacted negatively on WHAM, since the inherited military culture tended to privilege military efforts that counter-balanced WHAM efforts.

\section{Conclusion}

Although the SADF dedicated considerable resources and men to the effort at winning hearts and minds in the Namibian conflict, their efforts were dogged by the lack of unity of purpose and effort between the political, administrative, military and police domains.

In the first place, the SADF could not rely on adequate political direction. The South African political authorities presented the Namibian conflict in terms that would ensure support of its domestic constituency, and did this by consistently framing the war in terms of a communist threat. As a result, underlying factors that contributed to the conflict were not acknowledged or addressed and the effort at winning hearts and minds was impeded by the lack of an alternative cause that would resonate with the population. This lack of a credible cause must be seen in comparison with SWAPO's cause, namely its promise of complete freedom of South African interference and rule. In summary, South Africa's own presence in Namibia was the fundamental issue under contest, and when SWAPO refused to settle the conflict on South African terms the political authorities were unable to provide an alternative solution.

The disunity between the SADF and the administration was largely caused by a lack of adequately trained civil servants, who were either indifferent to, or lacked understanding of the importance of winning popular support. Since the SADF took over these tasks, the legitimacy of the administration, that was meant to govern the country after the military left, was undermined by showing up the administration's lack of ability in providing services to the population.

The deep disjuncture between the police and the SADF was rooted in differences on the most effective way of ensuring the population's cooperation. 
While the SADF hoped to win the people's allegiance by persuasion, Koevoet relied on fear and coercion. Since the population viewed the police and the army as part of the same security forces, the actions of Koevoet affected the attitude of the population toward the South African authorities as a whole. This lack of a unified effort was not seriously addressed and remained a problem right to the end of the war.

As has been shown, the SADF was not without its internal divisions, which ranged from top level all the way down. Arising from the imperative that the SADF had to convert from a conventional military force to a counterinsurgency force, contested issues were the role of the SADF in WHAM, and how much priority WHAM should have in relation to military efforts. Especially in Ovamboland, the problem remained of having to establish military control of the region, which led to measures that alienated the population.

While lack of unity between the SADF and the civil authorities and administration was a problem in all sectors along the Angolan border, the divisions between the SADF and the police, as well as within the SADF, were especially problematic in Ovamboland. If the election results of 1989 are taken to reflect the allegiance of the population, this seems to bear out McCuen's observation that efforts at WHAM were most effective in regions where military control had been fully established, although such a conclusion does not take into account that the Ovambo people represented SWAPO's support base. Still, since lack of unity translated into situations where efforts at winning hearts and minds were undermined by actions that were counterproductive to this effort, it must at least partly have contributed to a SWAPO victory at the ballot box.

\section{Endnotes}

${ }^{1}$ This article is based on a thesis submitted on 13 August 2010 to the Board of Examiners of Utrecht University, the Netherlands, in partial fulfilment of the requirements of the degree of Master of Arts in Conflict Studies and Human Rights.

${ }^{2}$ Author's interviews with Lt. Gen. Ian Gleeson (ret.), 9 March 2010, Pringle Bay; Lt. Gen. Joffel CP van der Westhuizen (ret.), 5 May 2010, Silverton; Maj. Gen. Chris Thirion, 13 May 2010, Pretoria; Maj. Gen. Chris van Zyl, 4 May 2010, Silverton; Brig. Gen. Gert Nel (ret.), 5 March 2010, Centurion; Brig. Gen. [Dr] Wim van der Waals (ret.) 3 March 2010, Centurion; Brig. Gen. Gert JC van Niekerk SM (ret.), 23 May 2010, Potchefstroom; Prof. Louis du 
Plessis (Col ret.), 8 March 2010, Goodwood; Prof. Deon Fourie, retired Professor of Strategic Studies at the University of South Africa (Unisa), 6 May 2010, Pretoria; Lt. Col. Sarel Karsten (ret.), 11 May 2010, Kimberley; Maj. Gen. André Kruger (ret.), 18 March 2010, Langebaan; Dr Ian Liebenberg, 16 March 2010, Saldanha; Col. AW (Rusty) van Rooyen, 30 March 2010, Parow; Dr JC Kriek van der Merwe (Cmdt ret.), 26 May 2010, Centurion.

${ }^{3}$ In the SADF, the concept of 'winning hearts and minds' included a host of activities known by various names, such as burgersake (civic action), komops (communication operations), ploeg en plant (plow and plant) and psy-ops (psychological operations). Unless distinctions are relevant, this article uses the term 'WHAM' for any activities aimed at gaining or maintaining the support of the population. However, at the time, the acronym was not used, and it does not appear in any official documents.

${ }^{4}$ Magnus Malan served as Head of the Army from 1973 to 1976 and as Chief of the SADF from 1976 to 1980, Constand Viljoen served as Head of the Army from 1976 to 1980 and Chief of the SADF from 1980 to 1985, Jannie Geldenhuys served as Head of the Army from 1976 to 1980 and Chief of the SADF from 1980 to 1985, Georg Meiring served as Head of the Army from 1990 to 1993 and Chief of the SADF from 1993 to 1994.

5 The "Burgersake agtergrondreeks" (Civil Affairs Background Series) 1-11. The publications dealt with topics such as "Civic action and the soldier" (Sept. 1976), "Behaviour orientation of the Bantu" (Feb. 1977), "The role of the population in revolutionary war" (Mar. 1978) and "War of the flea" (Jul. 1978).

${ }^{6}$ Author's interview with Brig. Gen. [Dr] Wim van der Waals (ret.), 3 March 2010, Centurion.

${ }^{7}$ Fraser, CA. Lessons learnt from past revolutionary wars. Unpublished manuscript, 1960-1964, 2-5.

${ }^{8}$ McCuen, JJ. The art of counter-revolutionary war. London: Faber and Faber, $1966,71$.

${ }^{9}$ Visser, JA. The South African Defence Force's contribution to the development of South West Africa. Pretoria: SADF Military Information Bureau, 1984, 7; 27.

${ }^{10}$ Private collection of Wim Hofsink (interviewed by author on 13 May 2010, Pretoria).

${ }^{11}$ Source: "Sektor 10 - Die soldaat se handboek oor Owambo" (Sector 10 - The soldier's textbook on Ovamboland), a photocopied document distributed among soldiers in the operational area. Copy in author's possession. According to Lt. Col. Sarel Karsten (ret.), interviewed by author, 11 May 2010, Kimberley, the document is probably based on work by ethnologists who worked for the SADF: Sarel Karsten, Basjan van Niekerk, Salomé Visser. 
${ }^{12}$ Sky-shout and ground-shout were methods by which messages were disseminated from an aircraft or vehicle through a powerful public address system. Author's interview with Maj. Gen. Chris van Zyl, 4 May 2010, Silverton.

${ }^{13}$ Department of Defence Archives (hereafter DOD Archives), HS OPS/328/1/1, Burgersake memorandum: SAW sielkundige aksieprogram, Pretoria, 16 July 1979, 6.

${ }^{14}$ DOD Archives, Pretoria, Burgersake agtergrondreeks no. 8: Die rol van die bevolking in rewolusionêre oorlog. SA Army HQ, Pretoria: Directorate Operations, 1979, 10.

15 Author's interviews with Gen. Georg Meiring (ret.), 12 May 2010, Silverton; Brig. Gen. As Kleynhans (ret.), 20 May 2010, Pretoria; Brig. Gen. Gert JC van Niekerk SM (ret.), 23 May 2010, Potchefstroom.

${ }^{16}$ Kleynhans, ASJ Col. Die stryd teen terreur in SWA/Namibië 1957-1987. Windhoek: SWA Gebiedsmag, 1988, 22.

${ }^{17}$ DOD Archives, Pretoria, H-Leër/GS8/328/1/1/1, Burgersake direktief 5/78, Riglyne vir SA Leër spesiale aksie gedurende 1978, 29 May 1978, 2; DOD Archives, Pretoria, White Paper on Defence and Armaments Supply 1979. Pretoria: DOD, 1979, 10.

${ }^{18}$ Atwood, JB. Nation building: The UN and Namibia. Washington, DC: National Democratic Institute for International Affairs, 1990, 130.

19 Author's interview with Cmdt Cas Bakkes (ret.), 7 May 2010, Pretoria.

${ }^{20}$ DOD Archives, Pretoria, H-Leër/GS8/328/1/1/1, op. cit. p. 9.

${ }^{21}$ DOD Archives, Pretoria, HS OPS/325/1, Civic Action Directive 1/78, Coordination of speeches, 14 March 1978, 1-2 and Civic Action Directive 3/79, 1979, Monthly themes, 2. For instance, the theme for May 1979 reads: "The SADF is a tough well-trained and well-equipped force. It is willing and able to strike at our enemies. Neighbouring states will serve their own best interests by refraining from antagonizing the RSA".

${ }^{22}$ Paratus was the SADF magazine for family members of serving SADF members.

${ }^{23}$ The Orange River forms the border between southern Namibia and South Africa.

${ }^{24}$ DOD Archives, Pretoria, H-Leër/GS8/328/1/1/1, op. cit. p. 9.

${ }^{25}$ DOD Archives, Pretoria, White Paper on Defence and Armaments Supply 1979. Pretoria: DOD, 1979, 1.

${ }^{26}$ Author's interview with Brig. Gen. As Kleynhans (ret.), 20 May 2010, Pretoria.

${ }^{27}$ Fraser, op. cit. p. 8.

${ }^{28} \mathrm{Du}$ Pisani, A. "State and society under South African rule". In Keulder, C. (ed), State, society and democracy: A reader in Namibian politics, Windhoek: Macmillan Education Namibia, 2000, 69.

${ }^{29}$ Author's correspondence with Gen. Constand Viljoen (ret.), 24 May 2010, Ohrigstad.

${ }^{30}$ Author's interview with Gen. Georg Meiring (ret.), 12 May 2010, Silverton.

31 Author's interviews with Maj. Gen. Chris Thirion (ret.), 13 May 2010, Pretoria and Brig. Gen. As Kleynhans (ret.), 20 May 2010, Pretoria. 
${ }^{32}$ Fraser, op. cit. p. 10.

${ }^{33}$ Author's interviews with Lt. Gen. Joffel CP van der Westhuizen (ret.), 5 May 2010, Silverton; Brig. Gen. [Dr] Wim van der Waals (ret.), 26 May 2010, Centurion; Prof. Kobus Kotze, retired Professor of Military History and Military Strategy at the SA Military Academy, 18 March 2010, Saldanha and Prof. Deon Fourie, retired Professor of Strategic Studies at Unisa, 6 May 2010, Pretoria.

${ }^{34}$ Du Pisani, op. cit. p. 71.

35 Author's interview with Prof. Thean Potgieter, 19 March 2010, SA Military Academy, Saldanha.

${ }^{36}$ Author's interview with Lt. Gen. Ian Gleeson (ret.), 9 March 2010, Pringle Bay.

${ }^{37}$ Author's correspondence with Gen. Constand Viljoen (ret.), 24 May 2010, Ohrigstad.

${ }^{38}$ McCuen, op. cit. pp. 56-57; 71; Fraser, op. cit. p. 22.

${ }^{39}$ Visser, op cit. p. 1.

${ }^{40}$ Du Pisani, op. cit. pp. 68-73.

${ }^{41}$ Author's correspondence with Gen. Constand Viljoen (ret.), 24 May 2010, Ohrigstad and interviews with Brig. Gen. Gert JC van Niekerk SM (ret.), 23 May 2010, Potchefstroom; Maj. Gen. Gert Opperman (ret.), 18 May 2010, Pretoria and Brig. Gen. [Dr] Wim van der Waals (ret.), 26 May 2010, Centurion.

${ }^{42}$ Visser, op. cit. p. 2.

${ }^{43}$ Author's e-mail correspondence with Col. Johann A Engelbrecht, 28 May 2010, Port Elizabeth.

${ }^{44}$ Author's interviews with Gen. Georg Meiring (ret.), 12 May 2010, Silverton; Lt. Gen. Ian Gleeson (ret.), 9 March 2010, Pringle Bay; Brig. Gen. As Kleynhans (ret.), 20 May 2010, Pretoria; Maj. Gen. Chris van Zyl, 4 May 2010, Silverton; Maj. RB du Preez (ret.), 14 May 2010, Hartbeespoort.

${ }^{45}$ DOD Archives, Pretoria, SWS2(SA)/789, 5 May 1979 and SWS2(SA)/787/29, 29 May 1979.

${ }^{46}$ Author's interviews with Gen. Georg Meiring (ret.), 12 May 2010, Silverton; Maj. Gen. Chris van Zyl, 4 May 2010, Silverton and Col. AW (Rusty) van Rooyen (ret.), 30 March 2010, Parow.

${ }^{47}$ Fraser, op. cit. pp. 22; 30 and McCuen, op. cit. pp. 61-62; 121; 147.

${ }^{48}$ Geldenhuys, J. Die wat gewen het: Feite en fabels van die bosoorlog. Pretoria: Litera Publikasies, 2007, 71.

${ }^{49}$ Sarel Theron, in an interview with M Cadman, 13 February 2008, Missing Voices - Oral History Project 2004-2008, Historical Papers, University of the Witwatersrand, Johannesburg.

${ }^{50}$ Author's interview with Maj. Anton Bosman, 7 March 2010, Bloubergstrand.

${ }^{51}$ Author's interviews with Gen. Georg Meiring (ret.), 12 May 2010, Silverton; Lt. Gen. Ian Gleeson (ret.), 9 March 2010, Pringle Bay; Brig. Gen. As 
Kleynhans (ret.), 20 May 2010, Pretoria and e-mail correspondence with Gen. Jannie Geldenhuys (ret.), 22 July 2010, Pretoria.

52 Author's interviews with Lt. Col. [Dr] Francois Vreÿ, 17 March 2010, SA

Military Academy, Saldanha and Maj. Gen. Chris Thirion (ret.), 13 May 2010, Pretoria.

53 Author's interviews with Lt. Gen. Ian Gleeson (ret.), 9 March 2010, Pringle Bay; Maj. RB du Preez (ret.), 14 May 2010, Hartbeespoort; Prof. Deon Visser, 16 March 2010 and Lt. Col. [Dr] Francois Vreÿ, 17 March 2010, both at SA Military Academy, Saldanha and Maj. Anton Bosman, 7 March 2010, Bloubergstrand.

${ }^{54}$ Author's interview with Dr Ian Liebenberg, 16 March 2010, SA Military Academy, Saldanha.

55 Author's interviews with Dr JC Kriek van der Merwe (Cmdt ret.), 26 May 2010, Centurion; Maj. RB du Preez (ret.), 14 May 2010, Hartbeespoort and Lt. Col. Sarel Karsten (ret.), 11 May 2010, Kimberley.

${ }^{56}$ DOD Archives, Pretoria, HSP/DOD/S/325/2, 30 November 1980, Bevelsinformasiebulletin no 1/80: Misbruik van militêre gesag wat lei tot moord. The memorandum by Gen. Constand Viljoen deals with two cases where members of the SADF were tried for murder. In the first case, a patrol found four men in the forbidden zone. After questioning the men, the soldiers asked their (unnamed) commander for instructions and were told to "write them off", after which the soldiers released the men across the border into Angola, then shot and killed them. The soldiers were sentenced to detention, which was then suspended. The second case concerned a soldier out on patrol, who told his fellow soldiers: "I feel like shooting myself a kaffertjie", and then shot and killed a local teenage boy. He was sentenced to two years' detention. The memorandum states that soldiers should not conclude that they may be prosecuted for carrying out their task. The soldier should not have to constantly doubt whether he should kill the enemy, but should consider whether immediate circumstances necessitate or justify taking possibly innocent lives.

${ }^{57}$ McCuen, op. cit. p. 61.

${ }^{58}$ McCuen, op. cit. pp. 57; 61.

${ }^{59}$ Author's interview with Maj. Gen. Chris van Zyl, 4 May 2010, Silverton.

${ }^{60}$ Author's interview with Prof. Annette Seegers, University of Cape Town, 23 March 2010, Cape Town. 